\title{
I'm Not Going to Tell You Cos You Need to Think About This': a Conversation Analysis Study of Managing Advice Resistance and Supporting Autonomy in Undergraduate Supervision
}

\author{
Marion West ${ }^{1}$ (ID
}

Accepted: 14 September 2020 / Published online: 27 October 2020

(C) Springer Nature Switzerland AG 2020

\begin{abstract}
This article, firstly, critically analyses a face-to-face supervision meeting between an undergraduate and a supervisor, exploring how the supervisor handles the twin strategies of fostering autonomy while managing resistance to advice. Conversation analysis is used as both a theory and a method, with a focus on the use of accounts to support or resist advice. The main contribution is the demonstration of how both the supervisor and the student are jointly responsible for the negotiation of advice, which is recycled and calibrated in response to the student's resistance. The supervisor defuses complaints by normalising them, and moving his student on to practical solutions, often with humour. He lists his student's achievements as the foundation on which she can assert agency and build the actions he recommends. Supervisor-student relationships are investigated through the lens of the affective dimensions of learning, to explore how caring or empathy may serve to reduce resistance and make advice more palatable. By juxtaposing physically present supervision with digitally mediated encounters, while acknowledging their mutual entanglement, the postdigital debate is furthered. In the context of Covid-19, and rapid decisions by universities to bring in digital platforms to capture student-teacher interactions, the analysis presented is in itself an act of resistance against the technical control systems of the academy and algorithmic capitalism.
\end{abstract}

Keywords Advice · Supervision · Relationships · Conversation analysis · Face-to-face

Marion West

M.West2@wlv.ac.uk

1 Senior Lecturer in Linguistics and Sociology Faculty of Arts, Business and Social Sciences, University of Wolverhampton, Mary Seacole Building (MH213), Camp Street, Wolverhampton, UK 


\section{Introduction}

This article presents a microanalysis of face-to-face undergraduate supervision. It adds to the literature on how relationality is constituted through advice sequences (Shaw 2013) but critically examines this topic in a postdigital context. Knox (2016) and Fawns, Aitken and Jones (2020a) remind us that in our postdigital age, in which students and staff are multiply connected, not all face-to-face interactions help build meaningful relationships. Chris Park's (2007) description of doctoral supervision as 'a secret garden' can be equally applied to undergraduate supervision; despite the prevalence of shared offices and overheard meetings, supervision remains a largely hidden encounter. During the recent pandemic, new dimensions might be considered too, as supervisors and students meet across commercial platforms that universities have hastily introduced.

This article explores a face-to-face supervision meeting with a media student planning her undergraduate dissertation. It is developed from previous research (West 2019a, b) which problematises who, if anyone, is to judge excellence in supervision, and whose excellence would be measured anyway. It is informed by the conversation analysis (CA) tradition, which is the main method for investigating naturally occurring talk, and its previous applications to institutional talk and more specifically to advice.

Two research questions (RQs) are addressed. (1) How do supervisors support students' autonomy? and (2) How do supervisors manage resistance? These are prominent themes in the literature in both higher education (HE) (Bowker 2012, Mayes 2015, Park 2014, Vehviläinen 2009a and 2009b, Waring 2007a and 2007b, Leyland 2018) and other institutional settings (Hepburn and Potter 2011, Muntigi 2013). This article contributes to work on the negotiation of advice and relationality in supervisory settings, where it is acknowledged that metrics do not record everything that is important (Fawns, Aitken and Jones 2020b). As one of the first CA studies of interaction between undergraduates and their supervisors in a UK setting, it demonstrates the staging of support for students' autonomy, which varies from a nudge to full direction, where humour is never far away. It reveals how the supervisory dyad build on resistance to tailor advice to the individual (and wonders how this can be done online and for the many).

\section{Exploring Supervision and Advice}

\section{Supervisory Roles, Expectations and Relationships}

Supervision is a process entailing a range of approaches which depend on the supervisor, the supervisee and their particular context. These may vary according to the 'needs, competencies, expectations, and philosophy of the supervisor and the supervisee' (Anderson 1988: 12). Traditionally, the role of the supervisor is to 'provide guidance, advice, instruction, encouragement, support' (Mac Keogh 2006: 20). However, it is best to refer to roles such as directors, project managers, providers of subject expertise, advisors, mentors and editors rather than a singular role (Rowley and Slack 2004). To this list, we can add promoter of self-efficacy (Mac Keogh 2006). These roles congregate at different ends of the control versus freedom or offering guidance versus support ranges. Marshall (2009) suggests that 
direction should be staged from higher levels of autocracy at the start, to abdication at the end of the process.

Masters and in particular doctoral supervision have attracted more research interest than undergraduate supervision. This study draws on some of this literature, while recognising that the goal for doctoral supervision of fully fledged researchers with 'competent autonomy' (Gurr 2001) is over-ambitious for first degrees and that 'wellsupported autonomy' (Oldmeadow n.d.) seems a safer and more appropriate goal for final year undergraduates. Undergraduate research autonomy is both a goal and a staged process (Wisker 2018: 1).

The undergraduate dissertation remains the hallmark of 'graduateness' in the UK and elsewhere (Derounian 2011: 91). Dissertations vary in length between 8000 and 15,000 words and are worth between 20 and 60 credits. Degree classification generally takes the dissertation grade into account, and students cannot graduate with honours without an independent study. There is consensus that the dissertation process is an 'emotional rollercoaster' (Shadforth and Harvey 2004: 149-150); Todd et al. (2004) cite Silén's (2003) analogy of 'chaos and cosmos' in which students are not only unsettled but also stimulated by the dissertation task. It is therefore not surprising that both pastoral and technical elements of the supervisory relationship contribute to producing a dissertation (Derounian 2011). When Derounian (2011) invited undergraduates to rank supervisor qualities, they ranked subject/literature knowledge top, while listing encouragement in 4th position, above structuring/steering/guiding, ranked 6th and placed empathy in 8th position.

According to Hagenauer and Volet (2014), teacher-student relationships are an under-researched area. When Greenbank and Penketh (2009) interviewed undergraduates about their dissertation experience, they found that supervisory relationships were the most significant themes, but did not explore how they are enacted. Shaw (2013) calls for more research on how relationality is constituted through advice sequences, a sequence being composed of at least two turns at talk, each produced by a different person. One facet of the supervisory relationship not given much attention in the HE, as opposed to the interactional literature (Benwell and Stokoe 2002) on supervision, is humour. This study contributes to knowledge in these areas.

Despite a growing literature on the deployment of conversational resources in academic settings, there do not appear to be many conversation analytic studies of undergraduate supervision. An exception is Henricson and Nelson (2017), whose cross-linguistic study compares advice in undergraduate supervision and writing centre meetings in Sweden and Finland. Other HE interactional research has focussed on settings such as peer tutoring (e.g. Waring 2007a and Park 2014) or writing conferences (e.g. Mayes 2015, Leyland 2018) where the power differential between the advice giver and advice receiver is less marked than with lecturers and students. Bowker (2012) looks at negotiating understanding and agreement in supervision meetings with international masters' students in Scotland. Additionally, I would suggest that it could be very interesting to undertake conversation analytic research in an online context, though this is beyond the scope of the current article.

There is not the space here to discuss the changing landscape of HE, which several sources claim has altered student expectations (e.g. Money et al. 2017). Certainly, consumer constructions of students do not adequately capture the subtle complexities of modern-day student realities (Tight 2013, O’Toole and Prince 2015). Transactions 
between students and tutors are central to 'student engagement', a strong predictor of success (Zepke and Leach 2010). However, this term has itself been critiqued for being a generic buzz phrase (Hayes 2018), where such policy discourse fails to engage in itself with the notion of the diversity and autonomy of individual students.

\section{Supporting Autonomy}

Researchers such as Michael Long (1996) see learner autonomy as a fixed trait, while for others, it can be developed (Macaskill and Taylor 2010). For the purposes of this study, the operational definition put forward by Macaskill and Taylor (2010: 357) was used, which suggests that autonomous learners 'take responsibility for their own learning, are motivated to learn, gain enjoyment from their learning, are open-minded, manage their time well, plan effectively, meet deadlines, are happy to work on their own, display perseverance when encountering difficulties and are low in procrastination when it comes to their work'.

Dissertations are promoted as an effective vehicle to develop the graduate attribute of autonomy (Todd et al. 2006). The challenge in undergraduate supervision is to provide sufficient support to cultivate initiative and self-reliance (Todd et al. 2004). Indeed, Río, Diaz-Vazquez and Maside (2017: 159) go so far as to claim that 'the undergraduate dissertation is characterised by a conflict between autonomy and support'. But as noted above, the interactional realities have received little attention. Hence, the second focus of this study is on how supervisors support autonomy.

\section{Managing Resistance and Negotiating Advice}

Even in an institutional environment in which advice is expected and sometimes requested, giving advice is still 'a tricky thing to do' (Shaw 2013: 217) and may be resisted. This study pays special attention to how resistance is both prevented and managed in advice negotiation. According to Brown and Levinson's (1987) model of politeness, advice is a face-threatening act in that it may threaten the recipient's positive face (Goffman 1976: 5), or their desire to be respected, as it calls into question their knowledge and competence. It also undermines their negative face, or desire to be unimpeded, in that it sets up some degree of obligation to follow the advice. Furthermore, advice which is unsolicited is more likely to be received as a face-threatening act (Goldsmith and Fitch 1997).

Clayman's definition of resistant responses to interviewer's questions as those 'that either decline to fully address the topical or action agenda of the question, or shift to a different agenda, or both' (Clayman 2013: 647) can be applied to advice reception. Resistance can be done in either an overt or covert way (Clayman 2013). Alignment is the process of matching or coordinating talk in such a way as to show support, agreement, convergence or similarity. Its converse is misalignment. Whereas active resistance clearly produces misalignment, passive resistance is achieved by withholding acceptance by means of a non-response or by diverting the conversation away from the advice (Barton et al. 2016). Active advice resistance can also be 'pre-emptive' in that it can be produced before the expert has delivered advice (Gill, Pomerantz and Denvir 2010). 
Resistance can also be done ambiguously, to signal either passive acceptance or resistance (Heritage and Sefi 1992). Dispreferred responses that disrupt the progressivity of the shared talk or that challenge underlying assumptions have also been labelled as resistant (Muntigi 2013). Preference in conversation analysis is understood in the sense of what is preferred for smooth, untroubled social interaction, in other words progressivity (Schegloff 2007). Preference is viewed from an interactional rather than a psychological standpoint. Normalising involves labelling something in the interaction as commonplace or interpreting it in an ordinary way. This may make any ensuing advice more palatable and therefore circumvent resistance. Svinhufvud et al. (2017) identify three uses for normalising in their study of academic counsellors: to support the student's position, to challenge the student or to present the student's problem as workable.

\section{Accounts}

Experts use a variety of tactics to reduce resistance, sometimes combining this with support for autonomy. Accounts have been conceptualised as 'explanatory talk used to propose a cause, to make plain, and to warrant' (Antaki 1994: 2). Studying them can illuminate what speakers choose to make accountable and what kinds of accounts are seen as legitimate and accessible. The advice giver tailors advice to the client or service-user both before and after the actual advice. Indeed, the professional's combined selection and sequencing of advice formulations have a bearing on how likely the advice is to be accepted. Following Waring (2007b: 368 ), accounts in advice giving are 'the reasoning provided to bolster the viability of the advice.' Accounts are used to counter and forestall resistance and so have an obvious bearing on RQ2. They are also used to do pedagogy (Waring 2007b); the type of account supervisors use may also reveal which role(s) they are orienting to. Accounts have been studied in primary care (Stivers 2005), psychiatric consultations (Angell and Bolden 2015), peer counselling (Waring 2007b), and academic writing tutorials with teaching assistants (Park 2014). There is a gap in the literature regarding their use in undergraduate supervision, which the current study intends to fill.

In her study of the position of accounts in graduate peer supervising, Waring (2007b) found that accounts were used to address face threat, to forestall resistance, and to do pedagogy, including socialising students into academic discourse. She found that accounts feature prominently in writing tutors' advice sequences, to the extent that approximately two-thirds involve an explanation. Problem-accounts explain what the trouble is, for example, 'you kind of drift a bit' and benefit-accounts point to the advantages of following the relevant advice for example 'that will save you time' (Waring 2007b: 372). Waring demonstrates that accounts are routinely found in the following sequential positions:

First position accounts: pre-advice

Second position accounts: immediately post-advice

Third position accounts: post-problematic uptake

Fourth position accounts: post-acceptance 
Hybrid: most commonly pre-advice plus post-acceptance (Waring 2007b)

These are the steps Park (2014: 367) identifies:

Step 1: Acknowledgment of tutor advice (e.g., 'yeah', upshot, repeat of key terms)

Step 2: Contrastive conjunction (e.g., 'but', 'the thing is')

Step 3: Epistemic statement (e.g., 'I feel/think x')

Step 4: Account for advice resistance

Park then applies the stepwise model to the supervisor's further negotiation and fine tuning of advice:

Step 1: Acknowledgment of student concern (e.g., 'right', 'that's true')

Step 2: Contrastive conjunction (e.g., 'but')

Step 3: Specified advice (e.g., reason/example)

\section{Acknowledging Advice}

Heritage and Sefi (1992) identify three main ways to display receipt of advice, which have been corroborated and extended. (1) Marked acknowledgement (MA) is typically signalled by oh (for news receipt) (Heritage 1984) and right (for acceptance), a partial repeat (Heritage and Sefi 1992) or okay (Guthrie 1997). Okay is generally combined with other tokens such as right, yeah or a future action, e.g. I'll do $X$ accepting the advice. (2) Unmarked acknowledgement (UMA), typically signalled by continuers such as $\mathrm{mm}, \mathrm{hm}$, yeh or that's right, conveys that the recipient was already aware of the information offered and/or that they do not consider it relevant to themselves. Such receipt tokens do not acknowledge or accept that talk as advice. Okay and right, unprefaced by oh, can fall into this category too. However, Park (2014) citing Silverman (1997) and Pudlinski (2002) notes that in certain sequential environments, UMAs may create ambiguity as they can show agreement as well as passive recipiency. Tutors may then push students for more marked acknowledgement (Bowker 2012). (3) Heritage and Sefi (1992) note that advice may be rejected with assertions of competence or knowledge. However, Hepburn and Potter raise the issue of how far such displays resist a proposed course of action 'rather than aligning with the trajectory of the advice by offering a shared perspective' (Hepburn and Potter 2011:218).

Waring (2007a) examines student orientation to their existing efforts while replying to advice. This serves to display their identity as effortful students who are aware of relevant gaps in their knowledge. Waring (2007a) builds on earlier work (e.g. Heritage and Sefi 1992) by distinguishing between simple and complex advice acceptance. Complex advice acceptance does something more than simply accept the advice. Acceptance is combined with claims of comparable thinking (Pudlinski 2002) (e.g. yes I thought the same thing or I understood that when I was doing it but I did not know how to do it) or with accounts, which are explored next. Waring (2007a: 133) explores the use of accounts combined with advice acceptance to portray the student's previous action as thoughtful rather than haphazard and hence himself as a competent student. She draws a parallel with the competing preference structure for compliment responses 
for both acceptance and autonomy established by Pomerantz (1978), in that the turn of the dispreferred action is designed with delay devices and only weak agreement tokens (e.g. yeah) or disagreement tokens (e.g. well). Although more research has been undertaken on advice delivery and reception, advice resistance and how it can lead to advice negotiation have received less attention until recently (e.g. Waring 2007a, 2007b, Vehviläinen 2009b, Park 2014, Leyland 2018).

\section{Methodology}

Conversation analysis is aimed at discovering the rules governing everyday interaction. CA is both 'a theoretical and methodological approach' (Psathas 1995: 3), grounded in ethnomethodology. Ethnomethodology 'often examines the processes through which the social world is made orderly and coherent' (Wiggins 2017: 243). CA aligns with constructionist and interpretivist principles in educational research. Its epistemological and ontological assumptions are that social interaction is orderly at all points and that interactants orient to that order, an order which can be discovered and described (Heritage 2008). This study attends to how advice is initiated, received and negotiated through various practices, a practice being any feature of a turn at talk which has a distinctive character, a specific location within the turn or sequence, and is distinctive in terms of the social action implemented by the turn (Heritage 2010). This research is interested in local outcomes, observable in members' practices, rather than distal outcomes, which are not accessible to conversation analysis. Interviewing students about their advice take-up in terms of both mental processes and the execution of their project is beyond the scope and aims of this study.

According to Garot and Berard (2011: 131), '[m]embership categories refer to identities, essentially and MCA [Membership Categorisation Analysis] centers around the study of identities as they are achieved or contested, organized and understood, within the practical contexts of social interaction and language use'. Sacks maintains that categories are 'relevant for the doing of some activity' (Sacks 1992: 597), thus linking MCA to CA's programme for investigating social action. MCA shares its ontological base with CA in that it roots itself in members', and not analysts', concerns. Nevertheless, the development of CA with its emphasis on sequential analysis largely disregarded MCA for some time. However, more recent attention (e.g. Stokoe 2012) has focused on its usefulness in combination with other research methods including CA. Comparing CA's 'juggernaut' to MCA's' milk float', Stokoe (2012) maintains that there is no need for CA to derail MCA and promotes a method to complement CA with MCA.

The main steps in MCA involve exploring when interactants engage in categorybound activities, which are 'those actions that are expectedly done by members of a particular category' (Butler and Weatherall 2006: 444) or invoke 'category-tied predicates' or characteristics which may express 'rights, obligations, and knowledge' (Stokoe 2012: 281). Categories such as the standardised relational pair of student/ teacher are omni-relevant in that participants prioritise their orientation to their category incumbency (Sacks 1972). Fitzgerald, Housley and Butler (2009: 46) maintain that knowledge displays show their relevance 'beyond the sequence being examined', whereas Gardner (2013: 594) argues that teacher/student roles are not as 'fixed and omnirelevant as some studies suggest'. Mayes (2015) analyses writing center 
sequences to see if and how participants orient to a particular membership category such as student-teacher or writer-reader. Notwithstanding this, she acknowledges that a pedagogic goal is for teachers to help their students become better writers, which encompasses teachers orienting to the writer-reader, with the result that the roles of student-teacher and writer-reader may coalesce at times.

\section{Data Collection and Transcription}

The data, from a wider study on advice sequences in undergraduate supervision meetings, was collected at a UK widening-participation university in Autumn 2013. Colleagues from Law and Humanities were approached on the basis of familiarity, but lecturers in the same department were deliberately not asked, as I did not want to combine research with working closely within my module teams. I was an insider to the extent that I am a lecturer of the HEI, but an outsider to the extent that the supervisory interactions were from outside of my discipline (Trowler 2011). Instead of viewing the insider-outsider in research positioning as a dichotomy, I see these as relative (Kerstetter 2012). Supervision may vary by discipline; hence, interaction may be different, a possibility this study acknowledges. I recognise that by approaching lecturers with whom I had a relationship, the sample may be biased in terms of its lack of representativeness of our diverse population. Although I had not seen the lecturers I approached in a pedagogic context, they may have been 'like me' in some way. I left the selection of a student up to the supervisor.

I deliberately opted for a 'light touch' in my involvement in the recruitment and data collection stages. Supervisors contacted their students on my behalf to request their participation, and the meetings were audio-recorded by the supervisor or the student. This does mean, however, that I have very little information concerning how often the particular students and supervisors met, and whether this was their first meeting or not, unless that is obvious from the data. It also means that I have no knowledge of the offline-online dynamic between the pair. Furthermore, gender dynamics, though not the focus of the current study, may have been at play. For example, males are socialised to take risks while females are socialised to capitulate in the face of challenge (Rosenfeld 2002).

Although research across collections of data is common, by focussing on individual sequences, and even a single case, the conversation analyst can gain a fuller picture of the unfolding interaction (Bolden and Angell 2017). Here, five sequences from one meeting, which lasted nearly $13 \mathrm{~min}$, are analysed in the order in which they occurred. These were selected to demonstrate the negotiation of advice. Audio-recording was selected to facilitate data collection; I acknowledge the significance of the embodied turn and the limitations resulting from the decision not to use video. The recordings were transcribed according to the conventions laid down by Jefferson (2004) (see Appendix).

\section{Analysis}

Once data is collected, Sidnell (2010: 30) suggests looking for patterns such as repetition and word selection, formulations and formats, which are all part of turn design, which takes account of what is being asked, when and to whom. Recipient 
design relates to 'the multitude of ways which display an orientation and sensitivity to the particular other(s) who are the co-participants' (Sacks et al. 1974: 727). Sidnell (2010: 30) also recommends using 'keys' to gain an analytic handle on data. Firstly, it is important to identify turn construction units (TCUs), which may be lexical, phrasal, clausal or sentential. These include possible utterance completion at the transition relevance place (TRP) where the turn could pass to another speaker. The turn-taking system allocates only one turn to a participant (Sacks, Schegloff and Jefferson 1974), so when a speaker anticipates that they will need more than one turn, they may alert the hearer to an upcoming expanded turn with intonational changes or alerts such as well (Heritage 2015). When participants continue past this point, what is achieved?

We join the supervisor and student $3 \mathrm{~min}$ into the meeting in which they have been thrashing out key issues in the project such as the focus, aims and methodology. As the sequence unfolds, the supervisor's orientation to directing her development as an independent student increases.

In Fig. 1, the supervisor displays his stance on it being the student's task to think through the structure of her dissertation. He sets up this particular advice sequence with a query about her thoughts, presumably on how she will structure her dissertation. He does this with an 'and-prefaced question' (lines 1-2), a device used to indicate a question's agenda-based character (Heritage and Sorjonen 1994). The student shows that she has given this topic some thought with 'well I was thinking' to preface her question: 'would I still be able to include ... or would that be going off' (lines 4-7), thereby orienting to the supervisor's entitlement to pass judgement and her need for validification (Vehviläinen 2009a).

The supervisor responds with a negative assessment: 'It seems like it's veering away on the tangential' (lines 12-13). He follows this up with a question about why the student thinks Jamie Oliver is 'so popular' (lines 13-14). The supervisor meets the student's response 'because he's relatable' with a creaky voiced 'Yeah', which may signal that he is less than convinced and wishes the student to continue, followed by a repaired question: 'But why: Wh - What is there about him?' aligning to his pedagogic goals to push the student to find answers for herself (lines 17-18).

After an awkward interaction (lines 19-24) consisting of the supervisor's quiet but hearable in-breath (line 20), a quiet hesitation marker: 'er:m', an answerable gap of $2.4 \mathrm{~s}$ and the student's claim of 'I don't know' (line 23) plus a longer gap of $3.2 \mathrm{~s}$, the supervisor glosses his advice with 'I mean those are the sort of questions you need to be thinking about' (line 25), thereby bringing the need for the student to take responsibility for her learning to the fore. His turn is designed to flush out resistance. The student produces two overlapping 'okays' in relatively weak acknowledgement, the first of which is stretched (line 26) and the second followed by laughter (line 28). These indicate less than full alignment with the supervisor's project.

The post-acceptance account, which is combined with further advice: 'I have my ideas but I'm not going to tell you yet cause you need to think about this' (lines 30-32) with its amplification of 'my' and stress on 'tell' serves to playfully underpin the advice by emphasising that it is the student's project, and not the supervisor's (line 34). This is difficult to resist. There are parallels here with the findings of Park (2012: 2006) in that tutors remind students of their project ownership.

Laughter during talk may signal 'trouble, limitation or insufficiency' (Hepburn and Potter 2010). Here it modulates the action of both student and the supervisor. Of 


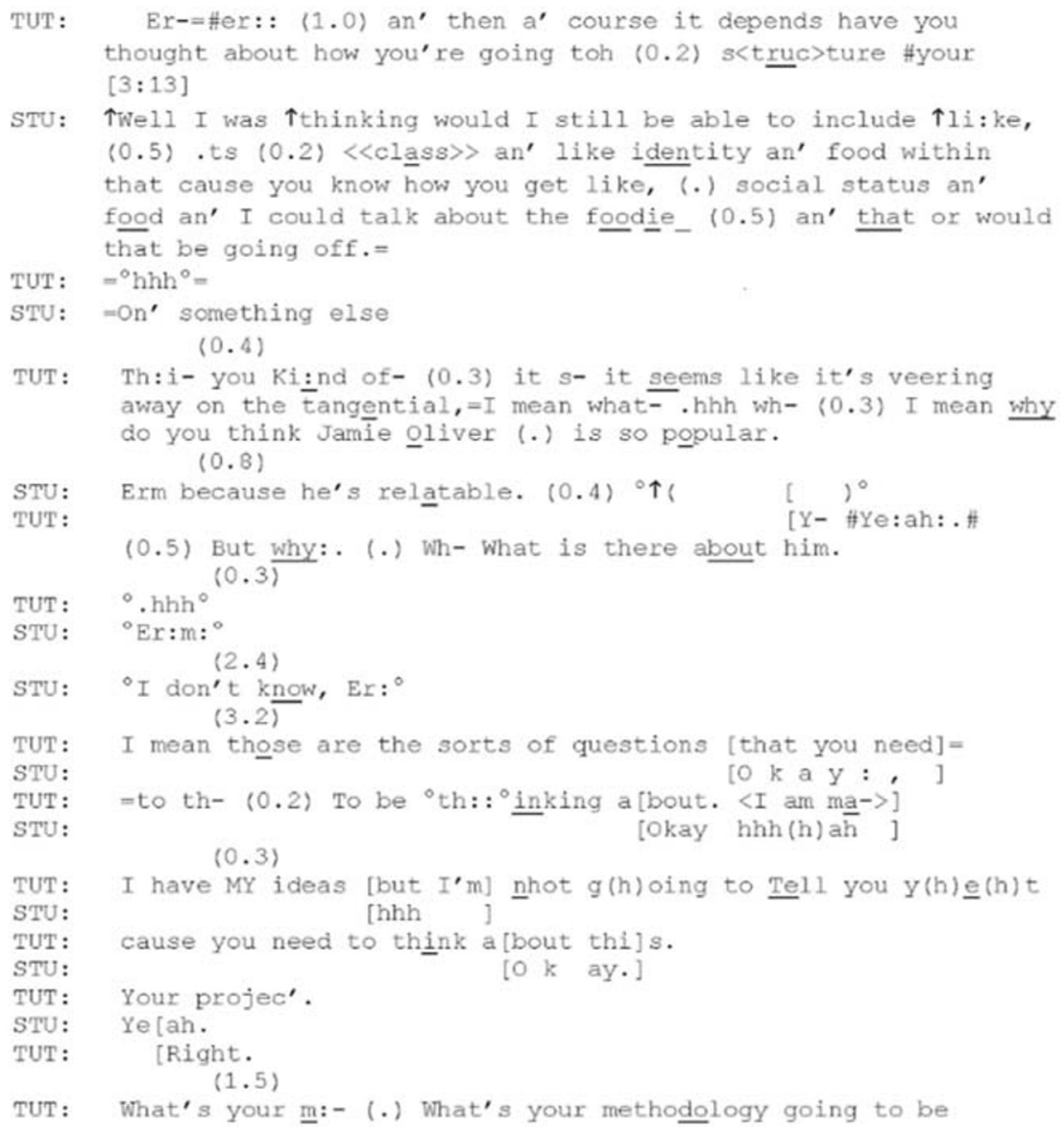

Fig. 1 Extract from 3.05 to $4.00 \mathrm{~min}$ (Be)cause you need to think about this. TUT tutor (supervisor); STU, student

interest is the order of the laughter, with the student laughing first, after an unmarked acknowledgement of the supervisor's directive: 'okay' (line 28). However, we have no access to any visual clues possibly inviting laughter. Then, the delivery with intermittent laughter softens and ironises the supervisor's refusal to share his ideas: 'I have my ideas but I'm not going to tell you' (line 30). Although 'laughing moments may be rife with power moments' (Glenn 2010:1497), here his action also appears to be designed to maintain relationality (Benwell and Stokoe 2002: 450). Furthermore, the interactional work undertaken by the supervisor prevents resistance.

The student acknowledges the combined account and advice with 'okay' (line 33), produced this time with falling intonation in overlap, which represents firmer acknowledgement (Bowker 2012). Nevertheless, the supervisor reinforces his point with 'your project' (line 34), to which the student replies with a different response token: 'yeah', again produced with falling intonation. So, although the student produces only minimal acknowledgement both before and after the account, her agreement tokens are produced with more receptive intonation after the tutor's account. The variation in her response tokens after 'your project' from 'okay' in three consecutive slots (lines 26, 28 
and 33) to 'yeah' may signal greater uptake (Schegloff 1982: 85). With 'right' (line 36) delivered with falling intonation, the supervisor accomplishes topic closure, moving to a new topic with 'What's your methodology going to be?' after a gap. He thereby remains in pedagogic mode by closing one topic and shifting to the next on his agenda.

Events in Fig. 2 occur nearly 7 min into the meeting, after the supervisor establishes what the student has read so far. This sequence opens with troubles-telling (Jefferson and Lee 1981), itself indicative of the student-tutor relationship as it is evidence of the student feeling sufficiently comfortable to reveal her difficulties. The supervisor normalises this emotion (Svinhufvud et al. 2017). This is the first occasion that the supervisor foregrounds the need to start writing. The student frames her complaint: 'it's really hard to juggle doing all the module stuff' (line 1) with an extreme case formulation (ECF): the selection of 'all the module stuff' emboldens her claim and 'locate(s) truth in the object being discussed, rather than in the eyes of the beholder' (Bischoping and Gazso 2016: 120).

However, the supervisor receipts this after a gap with a stand-alone, slightly stretched 'Y:ea', thus treating the problem description as normal and relatively unnewsworthy. After another silence he produces: 'Erm I have a little sympathy. Not-', with stress on a 'little' (line 6) and a cut-off 'not'. The normalising is done with a light touch in line with the supervisors in Svinhufvud et al. (2017), but with irony too. The action at this point may be to ostensibly support the student's position, while challenging her thinking. The student responds with laughter (line 7). Instead of topicalising the student's feelings, the supervisor moves on with his agenda to forward a workable

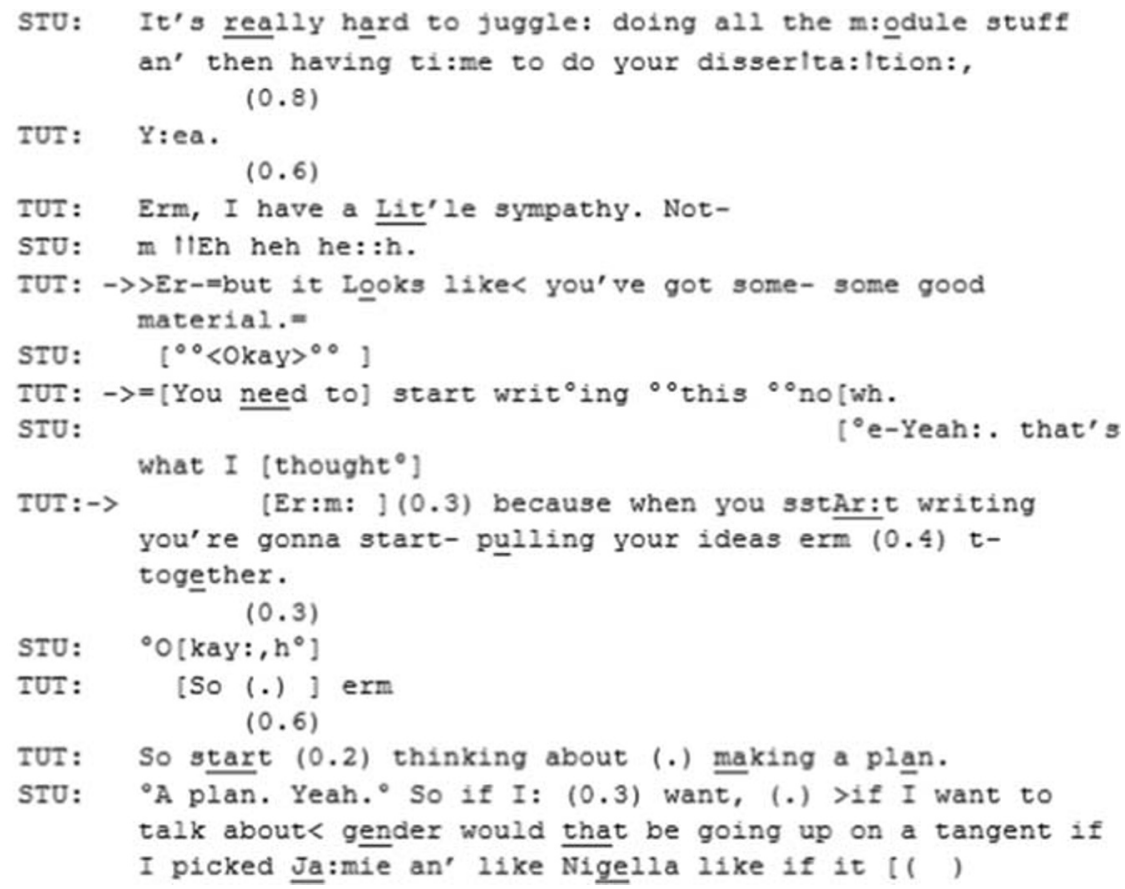

Fig. 2 Extract from 6.47 to 7.15 min: It's really hard to juggle. TUT, tutor (supervisor); STU, student 
solution. By fending off potential resistance, he may be able to pull off his forthcoming advice sequence.

'Er-but it looks like you've got some-some good material' (lines 8-9) is Janus-faced in that it looks back in counter position to her complaint but is also analysable as a normalising account in pre-advice position. Her problem is workable. Resistance may be minimised and she may be empowered as an autonomous learner to 'gain enjoyment from [their] learning' and 'display perseverance when encountering difficulties' (Macaskill and Taylor 2010: 357). But the student's very quiet, slowly delivered 'okay' does not present her as necessarily convinced (line 10). The supervisor delivers his bald advice with a necessity modal (need): 'You need to start writing this now'. The student receipts this with an unmarked acknowledgement: 'e-Yeah' on line 12.

One interpretation of the action done by the following quietly delivered 'that's what I thought' is that the student resists the supervisor's advice as newsworthy and reclaims her epistemic rights to pre-existing opinions on her own project. This is in line with Pudlinski's (2002) claims of prior thinking. An alternative interpretation is that by demonstrating a shared perspective, the student aligns herself with the supervisor's advice (Hepburn and Potter 2011: 218). Regardless of her stance, the supervisor ploughs on with his benefit-account, in which the 'start' in the proposed action to 'start writing' is both verbally emphasised and echoed in the resulting benefit: 'you're gonna start pulling your ideas together' (line 15). This forward-looking benefit-account is in line with Waring's (2007b) findings concerning supervisors solidifying advice. Furthermore, this is an example of recipient-designed advice, since much of the prior talk has pivoted around the need to find a focus for the project. In evidence is the supervisor's pursuit of his pedagogic goal to support the student's development towards this focus. His action foregrounds the student's responsibility for 'pulling' her 'ideas together'. The student receipts this with another quiet 'okay', stretched on this occasion and produced in turn-final overlap with the supervisor's first 'So' (lines 18-19).

In Fig. 3, the supervisor works up his concluding remarks, having already told the student: 'you need to start writing this now' (Fig. 2: line 11). The supervisor abandons and repairs 'yeah, I think we should try an' after the cut-off 'I-' (line 2). The 'Well' signals that what is to come is not straightforward or part of the original plan (Heritage 2015). The supervisor abandons his first action (which is likely to have been heading towards arranging another meeting) in favour of directing the student to undertake 'two things'. From now on, the advice is given baldly with a directive: 'First of all start writing' (line 3) as the supervisor orients to his role as Director, which may not be easy to resist. Although the student produces a marked acknowledgement in the form of a repeat of the directive, plus 'okay': 'start writing okay' (line 4), her rising intonation does not present her as entirely convinced. So the supervisor continues in overlap with a stronger directive to 'really start writing'. With 'I can't emphasize' (line 5), he invokes high entitlement before launching his authority-account in second position after the advice, implying that other students engage in erroneous thinking: 'cause too many students think I'll read and then I'll write' (lines 6 and 9).

Through not explicitly including her in this category of students, the supervisor can achieve two goals: he uses his enacted expertise as leverage in warning of the potential trap, while not accusing her of falling into it. Oppositional talk (Potter and Wetherell 1987) helps the supervisor to keep the student on his side and includes her in the 


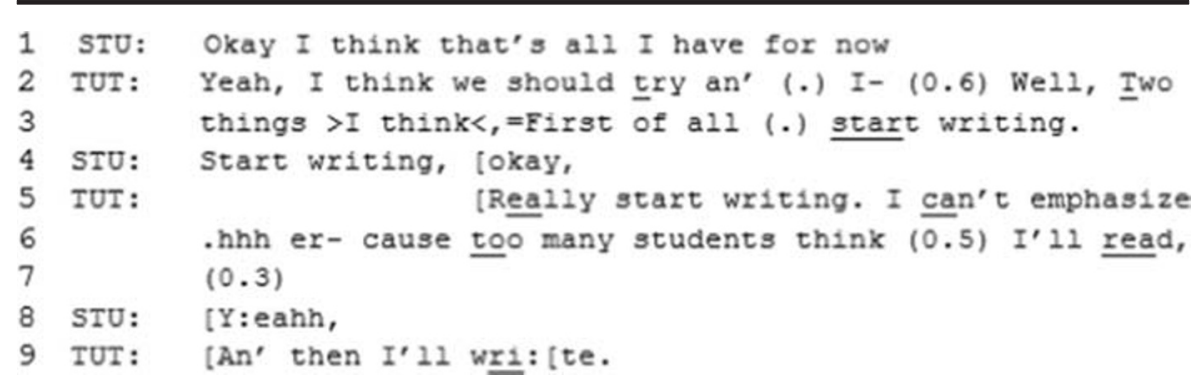

Fig. 3 Extract from 10.32 to 10.46 min: Too many students think I'll read... TUT, tutor (supervisor); STU, student

category of autonomous learners who are 'low in procrastination' (Macaskill and Taylor 2010: 357). He contrasts her with the noxious identities of that category of students who leave the writing until, he implies, it is too late. The advice is packaged as information that ostensibly may not be relevant to the student, though its underlying relevance to the recipient (Shaw 2013) should not be ignored. Resistance is therefore less likely.

The supervisor uses the negatively valanced 'too many', which he vocally emphasises. This is underlined by his broken-off, stressed 'I can't emphasize' (line 5). He uses the device of the present tense 'think' to represent a generalised, iterative present to formulate this as a routine though erroneous plan (Edwards 2000). Several features add weight to the misguided separation of the reading and writing process in the delivery of the problem-account: the gap (0.3) between the two actions of reading and writing, the stressed 'I'll read' and 'I'll write' and the combination of the conjunction 'and' with 'then'. A repeated, upgraded directive, combined with a professional authority account, may be difficult to resist.

So how does the student react to the warning not to delay writing? Analysed as an example of stepwise advice and resistance, Fig. 4 provides a clue that it will not be plain-sailing for the supervisor. In line with step 1 of Park's (2014) model, the student had acknowledged the supervisor's advice with a repeat of his instructions (Silverman 1997): 'start writing, okay' (Fig. 3: line 4). The supervisor then upgraded his advice with 'really start writing' (Fig. 3: line 5), as we saw further above. Initially, the student's overlapping 'Y:eahh,' at least partly, aligns with the supervisor's authority account (Fig. 3: line 8). However, her next turn follows step 2 of Park's model (Fig. 4: lines 1-2): she introduces her resistance with a disjunctive 'but', succeeded by a repaired epistemic statement (step 3) 'I've got-I'm confused', which serves as an account (step 4) built with her own extreme case formulation in 'all the readings' for why she cannot start writing. We cannot be sure where she was heading with the 'got', though 'confused' seems an obvious candidate. The repair 'I'm confused' highlights her current state of confusion. By explaining her own experience, the student claims epistemic primacy (Ekberg and LeCouteur 2015), which may put the supervisor in an awkward position. This is in line with the 'candidate obstacles', which patients put forward as a possible reason for not being able to follow lifestyle advice in diabetes consultations (Barton et al. 2016).

So how does the supervisor respond to her resistant display of emotion? Partly in line with the variations in Park's model (2014), he skips over fully acknowledging the 


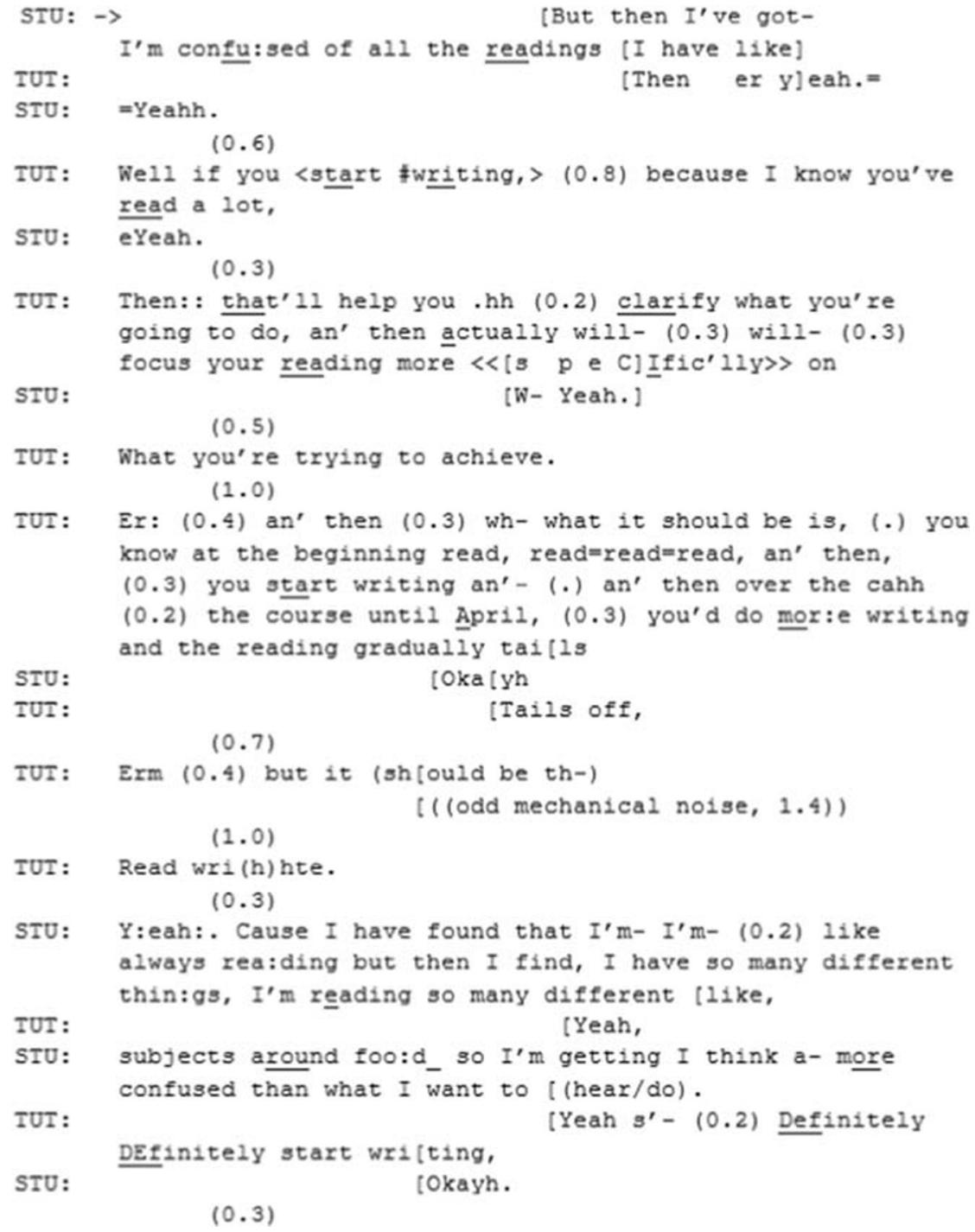

Fig. 4 Extract from 10.47 to $11.42 \mathrm{~min}$ : But then I've got confused. TUT, tutor (supervisor); STU, student

student's complaint that she's 'confused' (step 1). In common with the tutors in Svinhufvud, Voutilainen and Weiste (2017), the supervisor treats her emotion as commonplace and presents her problem as workable. But the transition to problem solving is not entirely smooth, as Svinhufvud et al. (2017) found in some cases of normalising. There are perturbations in his abandoned turn 'Then er yeah' (line 3) and a gap after the student's latched 'yeah' (line 4). He then signals that his turn will not be straightforward or expected with 'well'. This takes the place of the contrastive conjunction in Park's step 2 (2014). He then follows this with specified advice (step 3): 'If you start writing' which is delicately yet emphatically delivered, in that 'writing' is 
delivered with a creaky voice, possibly in acknowledgement of the student's difficulties. Furthermore, 'Start writing' is delivered at a slower speed and with emphasis on the 'start' and the first syllable of 'writing', perhaps to underline the significance and challenge of the desired action.

The recipient-designed reason 'because I know you've read a lot' (lines 6-7) inserted between the 'if' and 'then' elements utilises his knowledge of her extensive reading and aligns him with her recent account of 'all the readings' (line 2). She is unlikely to resist this account, which invokes her membership of the 'good student' category. Thus far in the meeting, the supervisor's authority-accounts have been used to mainly prevent resistance, but now, he uses an account based on shared knowledge of the student's reading: 'because I know you have read a lot' to counter resistance (lines 6-7). This recipient-designed account bears some similarity to the client-attentive accounts Angell and Bolden (2015) discuss in their study of psychiatric patients, in that it relates to the client's concerns, in this case the state of being 'confused of all the readings'. However, here the supervisor turns the 'problem' on its head by orienting to the benefits of having 'read a lot' as a foundation for the writing he now prescribes. He is able to temper his advice in accordance with her 'candidate problem' (Barton et al. 2016).

This move also coincides with that of the counsellors in Cromdal et al. (2018), who acknowledge their client's problem description on a young people's helpline by offering a solution both grounded in that description, yet recast. The client-attentive and authority-accounts are intertwined in that the supervisor both shows he recognises that the student has read and asserts his judgement over the quantity with 'a lot', where 'a lot' is a positive assessment of an activity in which students are expected to engage.

The supervisor uses the polarity between clarity and confusion in that the writing he advises will help her 'clarify what you're going to do', thus reducing her confusion. He places 'actually' in a counter-informing position to offset her claim (Clift 2001). He also capitalises on her focus on reading by asserting that the remedy he advises 'actually will- will- focus your reading more specifically on what you're trying to achieve' (lines 11-12, 15). This benefit-account is recipient-designed to play to her strengths (her extensive reading) and goals (completing her dissertation). Such positive personalisation of advice should bring her on board. Rather than orient to the institutional requirements to produce a dissertation, as he could have done with 'what we're asking you to do', the supervisor foregrounds the student's agency. Such highlighting of her agency may serve to both support her autonomy and manage resistance.

The supervisor follows this up with a script formulation (Edwards 1994) of the normal process of reading leading to writing (lines 17-21, 23, 25), on two occasions produced with an agentless 'it should be' (lines 17 and 25). He neatly summarises the dissertation cycle with 'read write' (line 28). Thus, he provides a professional authority account based on his expert knowledge of the dissertation cycle, temporarily removing the focus away from the individual student, which may be tricky to resist.

The student receipts his advice with a stretched 'Yeah' (line 30) and then reports on her dissertation work to date, which has resulted in her being 'more confused than I want to' (lines 34-35). Here the student may be resurrecting the problem to show understanding of the recipient-designed solution. This time she refers to her confusion as an account for advice uptake with: 'cause I have found...' (line 30), rather than her earlier contrast-marked 'but then I've got- I'm confused' (lines 1-2). She selects the full 
form: 'I have found' as opposed to the contracted form: 'I've found'. This may be to underline her ownership of that experience, or to emphasise that experience. Instead of focusing on the problem to which he has already provided a solution, which may lead to further resistance, the supervisor crystallises his advice with a repeated directive to 'definitely definitely start writing' (lines 36-37), delivered with high entitlement, which can be difficult to resist. This action shares its solution orientation with the counsellors in Svinhufvud et al. (2017). The student receipts this with 'okayh', delivered with a falling intonation contour to mark the completion of her turn (line 38). However, this is not the end of the sequence, as the supervisor continues his advice in Fig. 5.

Now he adds to the advice to start writing by reducing the stakes: 'don't worry if it doesn't get into your final submission' (lines 1-2). He follows this up with an objectside assessment (Edwards and Potter 2017): 'it's always a valid exercise to do'. This object-side assessment focuses on the writing activity rather than the tutor's disposition towards it, and is delivered with 'always', a 'Maximum Case proportional measure' (Pomerantz 1986: 223) of frequency to underline its invariable utility, regardless of the individual occasion. The student receipts this with another 'okayh' (line 4) delivered with slightly rising intonation, which here may display a weak epistemic stance or a questioning one (Hepburn and Bolden 2017: 41). This conveys that the student is not fully convinced.

So the supervisor volunteers information about his own writing process, prefaced by 'I mean' perhaps to specify the preceding advice. 'Whenever I write an article, I always have a folder that says edits' (lines 5-6) refers to a 'long-standing personal state of affairs' (Antaki et al. 2005: 190). Once more, ECFs on this occasion: 'whenever' and 'always', ratchet up the significance of the action and underline the routine. In line with the psychotherapeutic data in Leudar et al. (2006: 29), self-disclosure is rare in this data and is 'hearably relevant to what the client has said'. It may be used to normalise a client's problem, to model possible ways of dealing with it, or to even up the interaction (Priebe et al. 2011). It may be doing all three here, but perhaps particularly modelling a solution. Resisting what a supervisor himself practises may be awkward.

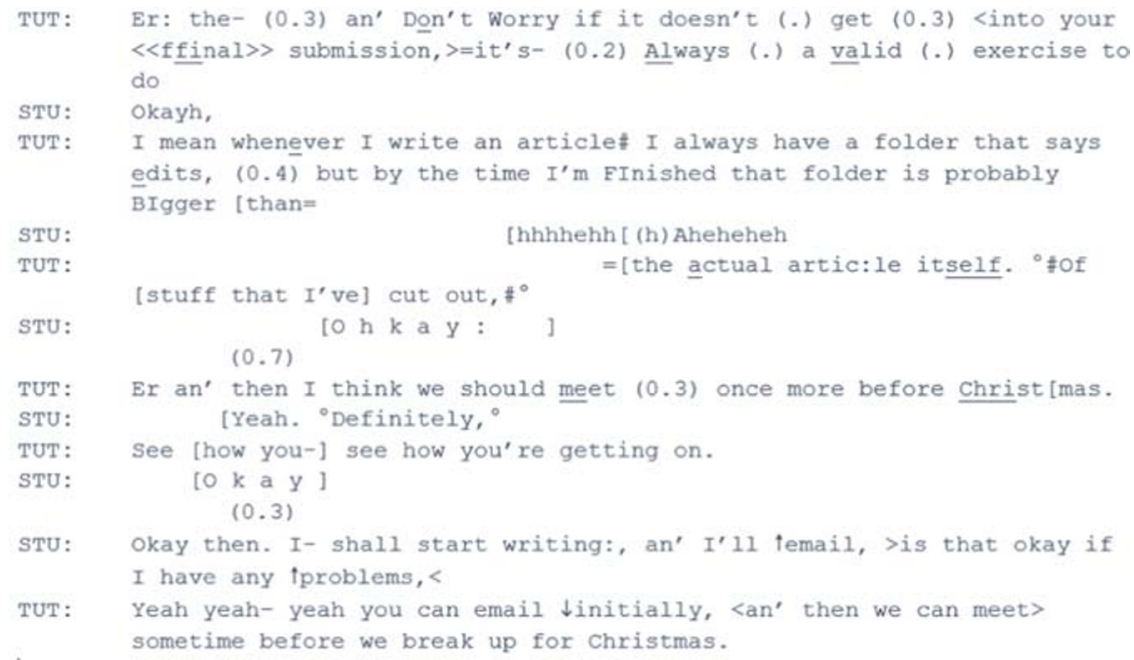

Fig. 5 Extract from 11.43 to $12.12 \mathrm{~min}$ : Whenever I write an article. TUT, tutor (supervisor); STU, student 
It could be argued that the supervisor is re-indexing himself as the more expert; people who write articles are more often established academics rather than undergraduates. However, it seems more likely that he is orienting to the autonomous writer category (Mayes 2015), referencing the student's and his co-membership (Benwell and Stokoe 2006) by sharing some of his pain as well as modelling his strategies. By stressing 'by the time I'm finished' and the relative size of the edits folder, the supervisor portrays his own writing practices with humour and humility. Earlier, the student recounted her experience of reading so much that it had left her 'confused'. Now in parallel, he offers a matched experience (Heritage and Lindström 1998) of iteratively pruning his writing. This action may be a vehicle for displaying empathy and relationship building, and designed to lessen resistance.

In overlap, the student receipts this revelation with laughter (line 8). The student acknowledges the end of the tutor's turn with 'ohkay's both followed by 0.7 second gaps, (line 11) which may be stretched to take up more interactional space in overlap (Hepburn and Bolden 2017). The supervisor then moves into a new sequence suggesting another meeting before Christmas (line 13). Finally, the student produces a marked uptake of his earlier advice: 'Okay then. I shall start writing' (line 19), delivered with a full modal form rather than a contracted 'I'll'. This promise embodies her commitment to a future action recommended by her tutor (Stevanovic 2011).

The analysis has shown how the supervisor uses Socratic questioning to help the student find her own focus, followed by a humorous refusal to provide solutions (Fig. 1). The student moves from complaining about juggling the demands of the final year (Fig. 2), and later her confused state (Fig. 4), to announcing her intention to 'start writing' (Fig. 5), thereby taking up the tutor's directive. This declaration comes at the end of a sequence in which the tutor has recourse to a number of devices and actions to counter her resistance. These include warning her about the category of students who put off writing (Fig. 3), tailoring the advice to her achievements and goals (Fig. 4), expounding on the writing process with script formulations (Fig. 4) and sharing his own writing practices (Fig. 5). Woven into the sequences are orientations to supporting the student's autonomy, particularly regarding effective planning and time management.

\section{Discussion}

As Goffman (1981) notes, laughter is a method for relating on a human rather than institutional level. In Figs. 1, 2 and 5, humour appears to lubricate the wheels of the supervisory encounter and manage resistance. While sympathising to some extent with the 'emotional rollercoaster' (Shadforth and Harvey 2004: 149) involved in juggling the demands of the final year, the supervisor uses humour to defuse the complaint and move the student on to a practical solution (Fig. 2). This action supports the student's developing autonomy in that she is offered the tools to overcome hurdles. If students are to develop their autonomy, they need opportunities to exercise decision-making; this supervisor pushes the student to consider points she does not appear to have given thought to, balancing scaffolding with a humorous refusal to provide her with all the answers. Whether or not others would feel comfortable with 'pulling off' such recipient design, is for them to judge, as is how they might do this in technology-mediated ways. 
Managing resistance and promoting autonomy are both conflicting and complementary forces. Indeed, 'doing being a supervisor' is often a matter of managing these forces as well as possible. The multiple roles of the supervisor can complicate this task. Meanwhile, students' positions can be viewed on two continua: compliance as opposed to resistance, and dependence as opposed to independence (Bowker 2012: 18). As Bowker argues, '[t]he role of the supervisor can then be seen as leading the student from dependence to independence whilst avoiding or overcoming resistance' (19). Whether either party may be tempted to take 'short cuts' in online communication, thus circumventing the careful negotiation of advice, including tailored, stepwise patterns, remains to be seen.

The detailed analysis of staff-student interaction provides valuable insights into the messy complexities of undergraduate supervisory relationships, which can be easily ignored in agendas to measure what is more easily measurable. How this fits into the wider sector aims of 'measuring excellence' warrants further discussion. Furthermore, amidst a global, market-led, neoliberal drive for universities to dramatically increase numbers of students (Jones 2019), how sustainable is one-to-one supervision? A critical postdigital perspective (Peters and Besley 2019) should help us make judgements about how best to combine both individualised and group, online and offline, supervision. Further research should explore the mutual entanglements between online and offline student-supervisor communication. A starting point could be orientation to different roles and affective displays (Pyyhtinen and Suoranta 2020). Such research also necessitates further application of politeness theory (Brown and Levinson 1987) and its developments to both technologically mediated communication and face-to-face encounters in the academy.

As both a method and approach, conversation analysis has much to contribute to investigating online communication and analysing this in a postdigital context. Indeed, CA 'can offer a unique insight into if, and how, technology impacts upon interactional practices' (Meredith 2019). With the development of media platforms, it will be interesting to see how particular organizational features such as repair and sequence organisation adapt and nest, or even, in the case of turn-taking for online written communication, disappear.

\section{Conclusion}

I have related the findings of Waring's (2007b) study on account positions and Park's (2014) work on stepwise sequences, also with peer tutors, to the more asymmetric site of undergraduate supervision, and applied the work of Svinhufvud et al. (2017) on normalising in study counselling to an alternative university context. This article has addressed two RQs concerning how tutors support student autonomy and manage resistance. The analysis has explored the tension between directing students and supporting their autonomy (both of which the student may resist), for instance with refusals to provide all the answers and encouragement for the student to own their project. The tutor walks a tightrope between institutional requirements and his professional authority, on the one hand, and support for the student's agency. Nonetheless, at this relatively early stage in this student's dissertation, his role as director rather than mentor prevails. 
I have shown that this student pushes back against advice with claims of epistemic primacy, and more subtly when she delivers unmarked acknowledgments such as 'okay', particularly when these are produced more quietly, with slightly raising intonation or stretched, showing that she may be less than convinced. The tutor counters resistance by not making heavy weather of problems, attending to her goals instead, which also serves to support her growing autonomy. Resistance is prevented with benefit accounts, in line with his solution focus. The tutor invokes various categories: the category of students who delay writing, the 'good student' who has 'read a lot' and the autonomous writers (including himself) who edit profusely.

Rather than topicalising student concerns, this supervisor focuses on alleviating them by providing the student with a solution to work on. Amid a 'growing cultural tendency to pathologise everyday emotions and responses' (Ecclestone and Hayes 2009/2019: xvi), the humorous, normalising treatment of this student's affective practices (Wetherall 2012) is refreshing. This stance serves to both reassure the student and lighten up the interaction, while attending to both the face needs of the student (Goffman 1976) and the institutional goal to manage resistance and support autonomy during the negotiation of advice. But it appears that not until the student 'feels heard' is the advice palatable, as evidenced by her eventual commitment to 'start writing'. Resistance has value in both asserting a student's ownership of their dissertation, and their experience thereof, and for moving students towards independence. It also facilitates the fine-tuning of advice.

This article contributes to the literature on the management of affect in institutional settings. It makes visible important affective practices, such as the supervisor's ways of caring, showing empathy and increasing student agency, which would otherwise remain hidden in more quantitative measures of excellence. In itself, it is an act of resistance against the big-datafied surveillance culture of HE (Knox 2019). In line with the critical philosophy of the postdigital, it values the relational and event-based process above abstraction and formalization (Peters and Besley 2019). I have demonstrated through this analysis that the feedback that occurs between a supervisor and a student is not adequately captured or understood through either the algorithms that collect data or the metrics that this process is based on. This is because there are deeply contextual factors that get overlooked. This is even more important now that so much supervision is (by necessity) taking place online.

The study provides readers with insights into certain supervisory interactions, the richness of which may enable them to be applied as appropriate to their own situations (Lincoln and Guba 1985). This standpoint reflects the criterion of transferability for qualitative research (Bryman 2001). It does not necessarily mean changing existing practices. Rather, for continuous professional development, sharing transcripts of recorded supervision meetings with supervisors can provide them with a more theorised understanding of situated practice, and of their own competencies. The Conversation-Analytic Role-play Method (Stokoe 2011), in which the trainer engages practitioners in a line by line uncovering of the transcript, synchronised with the recording, could be used to stimulate discussion and awareness of the choices available in interaction. This article also encourages readers to consider recording, analysing and sharing their own practice. With the increasing use of online delivery, the facility to record interactions means that they are easily available for our own reflective work and, with permissions, collegiate 
inquiry. Whether, and how, the 'datafied university' (Knox 2019) would (know how to) use recordings to evaluate the 'effectiveness' of staff-student rich dialogues (Knight and Littleton 2015) is another debate.

Acknowledgements This article is developed from my doctoral thesis (West 2019a) and from a paper presented at the Higher Education Institutional Research (HEIR) Conference: 'Measuring Excellence' in HE: Approaches and their Impact at University of Wolverhampton (West 2019b). The author wishes to thank the supervisor and student who agreed to record their meeting for the purposes of the wider study on which this article is based. She would also like to express her thanks to the University of Wolverhampton for research support and the organisers of the HEIR conference.

\section{Compliance with Ethical Standards}

Ethical Approval All procedures performed in studies involving human participants were in accordance with the ethical standards of the institutional committee (Faculty of Education, University of Wolverhampton) and with the 1964 Helsinki declaration and its later amendments or comparable ethical standards.

\section{Glossary of Transcript Symbols Based on Jefferson (2004)}

[ ] Brackets are used to represent overlapping talk at precise points in the talk.

$=\quad$ An equals sign represents no break or gap within one turn or between two different turns, where the ordinary beat of silence between turns has not been produced.

(0.3) A silence is measured to the nearest tenth of a second and placed in parenthesis.

(.) A silence that is less than two-tenths of a second (a micropause) is represented as a full stop in parentheses.

need Underlining of a word or a part of a word is used to mark a stressed production.

$:$ : Colons represent an extension of the prior sound.

ne:ed Underling and colons are used in combination to mark up-down contours. Where the letter is underlined and followed by a colon, as in this example, the pitch movement goes up and then down through the word. When the colon is underlined, the pitch is rising through the word.

$\uparrow \downarrow \quad$ Arrows are used to represent marked intonation shifts.

, $i \quad$ Punctuation markers are used to represent normal shifts in intonation. The question mark represents questioning intonation, the comma marks slightly rising intonation, while the upside down question mark represents rising intonation that is in between the two. A full stop in contrast marks falling intonation.

NEED Uppercase is used to represent talk that is louder relative to the surrounding talk.

${ }^{\circ}$ need $^{\circ} \quad$ Degree signs are used to represent talk that is quieter or softer relative to the surrounding talk.

$<$ need $>$ The use of the left/right carats in this order to surround talk, is used to represent the talk as being slowed down in comparison to the surrounding talk. 
$>$ need $<$ The use of the right/left carat in this order to surround talk, is used to represent the talk as speeded up or rushed through.

$<$ need A left hand carat at the beginning of a word is used to display that the utterance was 'jump started'.

nee- $\quad$ The hyphen is used to mark a word as being cut off.

need* An asterisk is placed after a consonant to represent a dentalised sound.

Nee\#d A croaky voice is represented by the hash symbol.

.hh Inbreaths are represented with a row of ' $h$ 's that have a full stop placed in front of them.

hh Outbreaths are represented by a row of 'h's with no full stop.

neehhd A row of ' $h$ 's within a word is used to display breathiness.

nee(h)d An ' $h$ ' that is parenthesized is used to represent plosiveness.

heh Laughter is represented by different combinations of ' $h$ 's and vowels.

huh

$£ \quad$ A pound symbol is used to mark a smiley voice.

(need) Single parenthesised words are used to represent an unsure hearing.

(( )) Double brackets represent the transcriptionist's comments.

\section{References}

Anderson, J. (1988). The supervisory process in Speech-language Pathology and Audilogy. Boston, MA: Little, Brown and Co.

Angell, B., \& Bolden, G. (2015). Justifying medical decisions in mental health care: Psychiatrists' accounts for treatment recommendation. Social Science and Medicine, 138, 44-56. https://doi.org/10.1016/j. socscimed.2015.04.029.

Antaki, C. (1994). Explaining and arguing: The social organization of accounts. London and Thousand Oaks: SAGE.

Antaki, C., Barnes, R., \& Leudar, I. (2005). Self-disclosure as a situated interactional practice. British Journal of Social Psychology, 44(2), 181-199. https://doi.org/10.1348/014466604x15733.

Barton, J., Dew, K., Dowell, A., Sheridan, N., Kenealy, T., Macdonald, L., Docherty, B., Tester, R., Raphael, D., Gray, L., \& Stubbe, M. (2016). Patient resistance as a resource: Candidate obstacles in diabetes consultations. Sociology of Health \& Illness, 38(7), 1151-1166. https://doi.org/10.1111/14679566.12447.

Benwell, B., \& Stokoe, E. (2002). Constructing discussion tasks in university tutorials: Shifting dynamics and identities. Discourse Studies, 4(4), 429-453. https://doi.org/10.1177/14614456020040040201.

Benwell, B., \& Stokoe, E. (2006). Discourse and identity. Edinburgh: Edinburgh University Press.

Bischoping, K., \& Gazso, A. (2016). Analyzing talk in the social sciences: Narrative, conversation and discourse strategies. London: Sage.

Bolden, G. B., \& Angell, B. (2017). The Organization of the Treatment Recommendation Phase in Routine Psychiatric Visits. Research on Language and Social Interaction, 50(2), 151-170. https://doi.org/10.1080 /08351813.2017.1301299

Bowker, D. (2012). 'Okay? Yeah? Right?': Negotiating understanding and agreement in master's supervision meetings with international students. Ph.D. Thesis. Stirling: University of Stirling. https://dspace.stir.ac. uk/bitstream/1893/12684/1/david\%20bowker\%20EdD\%20thesis.pdf. Accessed 2 June 2020.

Brown, P., \& Levinson, S. (1987). Politeness: Some universals in language usage. Cambridge: Cambridge University Press.

Bryman, A. (2001). Social research methods. Oxford: Oxford University Press.

Butler, C., \& Weatherall, A. (2006). 'No, we're not playing families': Membership categorisation in children's play. Research on Language and Social Interaction, 39(4), 441-470. https://doi.org/10.1207/s15327973 rlsi3904_4. 
Clayman, S. (2013). Conversation analysis in the news interview. In J. Sidnell \& J. T. Stivers (Eds.), Handbook of conversation analysis (pp. 630-656). Boston: Wiley-Blackwell.

Clift, R. (2001). Meaning in interaction: The case of 'actually'. Language, 77(2), 245-291.

Cromdal, J., Danby, S., Emmison, M., Osvaldsson, K., \& Cobb-Moore, C. (2018). 'Basically it's the usual whole teen girl thing': Stage-of-life categories on a children's and young people's helpline. Symbolic Interaction, 41(1), 25-44. https://doi.org/10.1002/symb.320.

Derounian, J. (2011). Shall we dance? The importance of staff-student relationships to undergraduate dissertation preparation. Active Learning in Higher Education, 12(2), 91-100. https://doi.org/10.1177 /1469787411402437.

Ecclestone, K., \& Hayes, D. (2009/2019). The dangerous rise of therapeutic education. London: Routledge.

Edwards, D. (1994). Script formulations: An analysis of event descriptions in conversation. Language and Social Psychology, 13(3), 211-247. https://doi.org/10.1177/0261927X94133001.

Edwards, D. (2000). Extreme case formulations: Softeners, investment, and doing nonliteral. Research on Language and Social Interaction, 33(4), 347-373. https://doi.org/10.1207/S15327973RLSI3304_01.

Edwards, D., \& Potter, J. (2017). Some uses of subject-side assessments. Discourse Studies, 19(5), 497-514. https://doi.org/10.1177/1461445617715171.

Ekberg, K., \& LeCouteur, A. (2015). Clients' resistance to therapists' proposals: Managing epistemic and deontic status. Journal of Pragmatics, 90, 12-25. https://doi.org/10.1016/j.pragma.2015.10.004.

Fawns, T., Aitken, G., \& Jones, D. (2020a). Online learning as embodied, socially meaningful experience. Postdigital Science and Education, 1(2), 293-297. https://doi.org/10.1007/s42438-019-00048-9.

Fawns, T., Aitken, G., \& Jones, D. (2020b). Ecological teaching evaluation vs the datafication of quality: Understanding education with, and around, data. Postdigital Science and Education. https://oi. org/10.1007/s42438-020-00109-4.

Fitzgerald, R., Housley, W., \& Butler, C. (2009). Omnirelevance and interactional context. Australian Journal of Communication, 36(3), 45-65.

Gardner, R. (2013). Conversation analysis in the classroom. In J. Sidnell \& T. Stivers (Eds.), The Handbook of Conversation Analysis (pp. 593-611). Oxford: Wiley-Blackwell.

Garot, R., \& Berard, T. (2011). Ethnomethodology and membership categorization analysis. In R. Wodak, B. Johnstone, \& P. Kerswill (Eds.), The Sage Handbook of Sociolinguistics (pp. 125-138). SAGE.

Gill, V. T., Pomerantz, A., \& Denvir, P. (2010). Pre-emptive resistance: patients' participation in diagnostic sense-making activities. Sociology of Health \& Illness, 32(1), 1-20. https://doi.org/10.1111/j.14679566.2009.01208.x.

Glenn, P. (2010). Interviewer laughs: Shared laughter and asymmetries in employment interviews. Journal of Pragmatics, 42(6), 1485-1498. https://doi.org/10.1016/j.pragma.2010.01.009.

Goffman, E. (1976). Interaction ritual: Essays on face-to-bace Behaviour. New York: Anchor.

Goffman, E. (1981). Forms of talk. Oxford: Blackwells.

Goldsmith, D., \& Fitch, K. (1997). The normative context of advice as social support. Human Communication Research, 23(4), 454-476. https://doi.org/10.1111/j.1468-2958.1997.tb00406.x.

Greenbank, P., \& Penketh, C. (2009). Student autonomy and reflections on researching and writing the undergraduate dissertation. Journal of Further and Higher Education, 33(4), 463-472. https://doi. org/10.1080/03098770903272537.

Gurr, G. M. (2001). Negotiating the "Rackety Bridge" — a Dynamic Model for Aligning Supervisory Style with Research Student Development. Higher Education Research \& Development, 20(1), 81-92. https://doi.org/10.1080/07924360120043882.

Guthrie, A. (1997). On the Systematic Deployment of okay and mmhmm in Academic Advising Sessions. Pragmatics, 7(3), 397-415.

Hagenauer, G., \& Volet, S. (2014). Teacher-student relationship at university: An important yet underresearched field. Oxford Review of Education, 40(3), 370-388. https://doi.org/10.1080 /03054985.2014.921613.

Hayes, S. (2018). Invisible labour: Do we need to reoccupy student engagement policy? Learning and Teaching, 11(1), 19-34. https://doi.org/10.3167/latiss.2018.110102.

Henricson, S., \& Nelson, M. (2017). Giving and receiving advice in higher education. Comparing SwedenSwedish and Finland-Swedish supervision meetings. Journal of Pragmatics, 109, 105-120. https://doi. org/10.1016/j.pragma.2016.12.013.

Hepburn, A., \& Bolden, G. (2017). Transcribing for social research. Thousand Oaks, CA: Sage.

Hepburn, A., \& Potter, J. (2010). Interrogating tears: Some uses of 'tag questions' in a child protection helpline. In A. Freed \& S. Ehrlich (Eds.), 'Why do you ask?': The function of questions in institutional discourse (pp. 69-86). New York: Oxford University Press. https://doi.org/10.1093 /acprof:oso/9780195306897.003.0004. 
Hepburn, A., \& Potter, J. (2011). Designing the recipient: Managing advice resistance in institutional settings. Social Psychology Quarterly, 74(2), 216-241. https://doi.org/10.1177/0190272511408055.

Heritage, J. (2010). Conversation analysis: Practices and methods. In D. Silverman (Ed.), Qualitative research: Theory, method and practice (3rd ed., pp. 208-230). London: Sage.

Heritage, J. (1984). A change-of-state token and aspects of its sequential placement. In J. Atkinson \& J. Heritage (Eds.), Structures of social action: Studies in conversation analysis (pp. 299-345). Cambridge: Cambridge University Press.

Heritage, J. (2008). Conversation analysis as social theory. In B. Turner (Ed.), The new Blackwell companion to social theory (pp. 300-320). Oxford: Blackwell. https://doi.org/10.1002/9781444304992.ch15.

Heritage, J. (2015). Well-prefaced turns in English conversation: A conversation analytic perspective. Journal of Pragmatics, 88, 88-104. https://doi.org/10.1016/j.pragma.2015.08.008.

Heritage, J., \& Sefi, S. (1992). Dilemmas of advice: Aspects of the delivery and reception of advice in interactions between health visitors and first time mothers. In P. Drew \& J. Heritage (Eds.), Talk at work: Interaction in institutional settings (pp. 359-419). Cambridge: Cambridge University Press.

Heritage, J., \& Sorjonen, M. (1994). Constituting and maintaining activities across sequences: And-prefacing as a feature of question design. Language in Society, 23, 1-29. https://doi.org/10.1017 /S0047404500017656.

Heritage, J., \& Lindstrom, A .(1998). Motherhood, Medicine, and Morality: Scenes From a Medical Encounter. Research on Language \& Social Interaction, 31(3-4), 397-438. https://doi.org/10.1080 /08351813.1998.9683598.

Jefferson, G. (2004). Glossary of transcript symbols with an introduction. In G. Lerner (Ed.), Conversation analysis: Studies from the first generation (pp. 13-32). Amsterdam: John Benjamins.

Jefferson, G., \& Lee, J. (1981). The rejection of advice: Managing the problematic convergence of a 'troublestelling' and a 'service encounter'. Journal of Pragmatics, 5, 399-421. https://doi.org/10.1016/0378-2166 (81)90026-6.

Jones, C. (2019). Capital, neoliberalism and educational technology. Postdigital Science and Education, 1(2), 288-292. https://doi.org/10.1007/s42438-019-00042-1.

Kerstetter, K. (2012). Insider, outsider, or somewhere in between: The impact of researchers' identities on the community-based research process. Journal of Rural Social Sciences, 27(2), 99-117.

Knight, S., \& Littleton, K. (2015). Dialogue as data in learning analytics for productive educational dialogue. Journal of Learning Analytics, 2(3), 111-143. https://doi.org/10.18608/jla.2015.23.

Knox, J. (2016). Posthumanism and the massive open online course: Contaminating the subject of global education. London: Routledge.

Knox, J. (2019). What does the 'postdigital' mean for education? Three critical perspectives on the digital, with implications for educational research and practice. Postdigital Science and Education, 1(2), 357370. https://doi.org/10.1007/s42438-019-00045-y.

Leudar, I., Antaki, C., \& Barnes, R. (2006). When psychotherapists disclose personal information about themselves to clients. Communication and Medicine, 3(1), 27-41. https://doi.org/10.1515/cam.2006.004.

Leyland, C. (2018). Resistance as a resource for achieving consensus: Adjusting advice following competency-based resistance in L2 writing tutorials at a British University. Classroom Discourse, 9(3), 267-287. https://doi.org/10.1080/19463014.2018.1480966.

Lincoln, Y., \& Guba, G. (1985). Naturalistic enquiry. Newbury Park, CA: Sage.

Long, M. (1996). The role of the linguistic environment in second language acquisition. In W. Ritchie \& T. Bathia (Eds.), Handbook of second language acquisition (pp. 413-469). San Diego, CA: Academic Press.

Mac Keogh, K. (2006). Supervising undergraduate research using online and peer supervision. In M. Huba (Ed.), 7th International Virtual University Conference, Bratislava 14-15 December (pp. 19-24). Bratislava: Technical University Bratislava.

Macaskill, A., \& Taylor, E. (2010). The development of a brief measure of learner autonomy in university students. Studies in Higher Education, 35(3), 351-359. https://doi.org/10.1080/03075070903502703.

Marshall, S. (2009). Supervising projects and dissertations. In H. Fry, S. Ketteridge, \& S. Marshall (Eds.), A handbook for teaching and learning in higher education enhancing academic practice (3rd ed., pp. 150155). Abingdon: Routledge.

Mayes, P. (2015). Becoming an 'autonomous writer': Epistemic stance displays and membership categorization in the writing conference. Discourse Studies, 17(6), 752-769. https://doi.org/10.1177 $/ 1461445615602375$.

Meredith, J. (2019). Conversation Analysis and Online Interaction. Research on Language and Social Interaction, 52(3), 241-256. https://doi.org/10.1080/08351813.2019.1631040 
Money, J., Nixon, S., Tracy, F., Hennessy, C., Ball, E., \& Dinning, T. (2017). Undergraduate student expectations of university in the United Kingdom: What really matters to them? Cogent Education, 4(1), 1-11.

Muntigi, P. (2013). Resistance in couples counselling: Sequences of talk that disrupt progressivity and promote disaffiliation. Journal of Pragmatics, 49(1), 18-37. https://doi.org/10.1016/j. pragma.2013.01.003.

O'Toole, P., \& Prince, N. (2015). The psychological contract of science students: Social exchange with universities and university staff from the students' perspective. Higher Education Research and Development, 34(1), 160-172. https://doi.org/10.1080/07294360.2014.934326.

Oldmeadow, J. (n.d.) Supervising undergraduate research projects. https://studylib.net/doc/5420503 /supervising-undergraduate-projects. Accessed: 3 January 2019.

Park, C. (2007). Redefining the doctorate. York: Higher Education Authority.

Park, I. (2012). Seeking advice: Epistemic asymmetry and learner autonomy in writing conferences. Journal of Pragmatics, 44, 2004-2021. https://doi.org/10.1016/j.pragma.2012.09.012.

Park, I. (2014). Stepwise advice negotiation in writing center peer supervisoring. Language and Education, 28(4), 362-382. https://doi.org/10.1080/09500782.2013.873805.

Peters, M., \& Besley, T. (2019). Critical philosophy of the postdigital. Postdigital Science and Education, 1(1), 29-42. https://doi.org/10.1007/s42438-018-0004-9.

Pomerantz, A. (1978). Compliment responses: notes on the cooperation of multiple constraints. In J. Schenkein (Ed.), Studies in the organization of conversational interaction (pp. 79-112). New York: Academic Press.

Potter, J., \& Wetherell, M. (1987). Discourse and social psychology: Beyond attitudes and behaviour. London: Sage.

Priebe, S., Dmic, S., Wildgrube, C., Jankovic, J., Cushing, A., \& McCabe, R. (2011). Good communication in psychiatry - A conceptual review. European Psychiatry, 26, 403-407. https://doi.org/10.1016/j. eurpsy.2010.07.010.

Psathas, G. (1995). Conversation analysis: The study of talk-in-interaction. Thousand Oaks, CA: Sage.

Pudlinski, C. (2002). Accepting and rejecting advice as competent peers: Caller dilemmas on a warm line. Discourse Studies, 4(4), 481-499. https://doi.org/10.1177/14614456020040040501.

Pyyhtinen, O., \& Suoranta, J. (2020). Lecture as an event in postdigital education: A dyadic teaching diary. Postdigital Science and Education, 2(2), 348-364. https://doi.org/10.1007/s42438-020-00104-9.

Río, M., Diaz-Vazquez, M., \& Maside, J. (2017). Satisfaction with the supervision of undergraduate dissertations. Active Learning in Higher Education, 19(2), 159-172. https://doi.org/10.1177 /2F1469787417721365.

Rosenfeld, R. (2002). What do we learn about difference from the scholarship on gender? Social Forces, 81(1), 1-24.

Rowley, J., \& Slack, F. (2004). What is the future for undergraduate dissertations? Education and Training, 46(4), 176-181.

Sacks, H. (1972). An initial investigation of the usability of conversational data for doing sociology. In D. Sudnow (Ed.), Studies in social interaction (pp. 31-74). New York: Free Press.

Sacks, H. (1992). Lectures on conversation, Vol. 1 and 2. Oxford: Blackwell.

Sacks, H., Schegloff, E., \& Jefferson, G. (1974). A simplest systematics for the organization of turn-taking for conversation. Language, 50, 696-735.

Schegloff, E. (1982). Discourse as an interactional achievement: Some uses of 'uh huh' and other things that come between sentences. In D. Tannen (Ed.), Analyzing discourse: Text and talk (pp. 71-93). Washington, DC: Georgetown University Press.

Schegloff, E. (2007). Sequence organization in interaction: Volume 1: A primer in conversation analysis. Cambridge: Cambridge University Press.

Shadforth, T., \& Harvey, B. (2004). The undergraduate dissertation: Subject-centred or student-centred? Electronic Journal of Business Research Methods, 2(2), 145-152.

Shaw, C. (2013). Advice giving in telephone interactions between mothers and their young adult daughters. Ph.D. Thesis. Loughborough: Loughborough University.

Sidnell, J. (2010). Conversation analysis: An introduction. Chichester: Wiley-Blackwell.

Silén, C. (2003). Responsibility and independence in learning - What is the role of the educators and the framework of the educational programme. 11th Improving Student Learning: Theory, Research and Scholarship Leicestershire September.

Silverman, D. (1997). Discourses of Counselling: HIV counselling as social interaction. London: Sage.

Stevanovic, M. (2011). Participants' deontic rights and action formation: The case of declarative requests for action. Interaction and Linguistic Structures, 52, 1-37. 
Stivers, T. (2005). Parent resistance to physicians' treatment recommendations: One resource for initiating a negotiation of the treatment decision. Health Communication, 18(1), 41-74. https://doi.org/10.1207 /s15327027hc1801_3.

Stokoe, E. (2011). Simulated interaction and communication skills training: The 'conversation analytic roleplay method'. In C. Antaki (Ed.), Applied conversation analysis: Intervention and change in institutional talk (pp. 119-139). Basingstoke: Palgrave Macmillan. https://doi.org/10.1057/9780230316874_7.

Stokoe, E. (2012). Moving forward with membership categorization analysis: Methods for systematic analysis. Discourse Studies, 14(3), 277-303. https://doi.org/10.1177/1461445612441534.

Svinhufvud, K., Voutilainen, L., \& Weiste, E. (2017). Normalizing in student counseling: Counselors' responses to students' problem descriptions. Discourse Studies, 19(2), 196-215. https://doi.org/10.1177 /1461445617691704.

Tight, M. (2013). Students: Customers, clients or pawns? Higher Education Policy, 26(3), 291-307.

Todd, M., Bannister, P., \& Clegg, S. (2004). Independent inquiry and the undergraduate dissertation: Perceptions and experiences of final-year social science students. Assessment and Evaluation in Higher Education, 29(3), 335-355. https://doi.org/10.1080/0260293042000188285.

Todd, M., Smith, K., \& Bannister, P. (2006). Supervising a social science undergraduate dissertation: Staff experiences and perceptions. Teaching in Higher Education, 11(2), 161-173. https://doi.org/10.1080 $/ 13562510500527693$.

Trowler, P. (2011). Researching your own institution. London: British Educational Research Association. www.bera.ac.uk/researchers-resources/publications/researching-your-own-institution-higher-education. Accessed 2 June 2020.

Vehviläinen, S. (2009a). Student-initiated advice in academic supervision. Research on Language and Social Interaction, 42(2), 163-190. https://doi.org/10.1080/08351810902864560.

Vehviläinen, S. (2009b). Problems in the research problem: Critical feedback and resistance in academic supervision. Scandinavian Journal of Educational Research, 53(2), 185-201. https://doi.org/10.1080 /00313830902757592.

Waring, H. Z. (2007a). Complex advice acceptance as a resource for managing asymmetries. Text and Talk, 27(1), 107-137. https://doi.org/10.1515/TEXT.2007.005.

Waring, H. Z. (2007b). The multi-functionality of accounts in advice giving. Journal of SocioLinguistics, 11(3), 367-369. https://doi.org/10.1111/j.1467-9841.2007.00328.x.

West, M. (2019a). Managing advice resistance and supporting autonomy in undergraduate supervision: A conversation analytic study. $\mathrm{PhD}$ Dissertation. Wolverhampton University of Wolverhampton.

West, M. (2019b). I'm not going to tell you cos you need to think about this. Higher Education Institutional Research (HEIR) Conference 2019. Wolverhampton: University of Wolverhampton.

Wetherall, M. (2012). Affect and Emotion: A New Social Science Understanding. London: Sage.

Wiggins, S. (2017). Discursive psychology: Theory, method and applications. London: Sage.

Wisker, G. (2018). Frameworks and freedoms: Supervising research learning and the undergraduate dissertation. Journal of University Teaching and Learning Practice, 15(4).

Zepke, N., \& Leach, L. (2010). Improving student engagement: Ten proposals for action. Active Learning in Higher Education, 11(3), 167-177. https://doi.org/10.1177/1469787410379680. 